\title{
Assessment of environmental quality by the diversity of epiphytic lichens in a semi-arid Mediterranean area (Val Basento, South Italy)
}

\author{
Luca Paoli $^{1}$, Anna Guttová ${ }^{2} \&$ Stefano Loppi ${ }^{1}$ \\ ${ }^{1}$ Department of Environmental Sciences, University of Siena, Via P. A. Mattioli 4, I-53100 Siena, Italy; tel.: +39-0577- \\ 235415, fax:+39-0577-232896,e-mail: paoli4@unisi.it,loppi@unisi.it \\ ${ }^{2}$ Institute of Botany, Slovak Academy of Sciences, Dúbravská cesta 14, SK-84523 Bratislava, Slovakia; tel.: +421-2- \\ 59426143, fax: +421-2-54771948, e-mail: anna.guttova@savba.sk
}

\begin{abstract}
The results of a bioindication study based on the diversity of epiphytic lichens in a semi-arid area of South Italy are presented. The area features the presence of an industrial zone located in a rural context. The survey was performed in 20 sampling sites. The lichen diversity values (LDV) were determined by the frequencies of all lichen species within a sampling grid placed on tree trunks. Lichens demonstrated a condition of environmental alteration extending to the industrial zone, and tending towards a recovery in the rural surroundings. The survey also showed evidence of eutrophication all over the study area.
\end{abstract}

Key words: Basilicata, bioindication, air pollution, eutrophication, industrial zone

\section{Introduction}

Recently, lichenological surveys have been an inherent part of comprehensive bioindication studies. In 2002, after international panel discussions, a great number of methods for quantifying interactions between lichens and the environment they live in, were collected, screened, classified, updated and summarily published (NImis et al., 2002) with the aim to be used broadly, and thus to gain comparable results from diverse geographical and climatic zones.

One of the methods for numerical interpretation of environmental quality is the assessment and calculation of lichen diversity values (LDVs), based on frequencies of the occurrence of lichen species on defined surface of a tree trunk (AsTA et al., 2002) together with interpretation of the obtained results in terms of deviation from normal/natural situations (LopPI et al., 2002b).

The applicability of LDV method is however subjected to the presence of suitable sampling substrates (ANPA, 2001). In most central and northern European areas this aspect is generally not regarded as a problem, but in dry Mediterranean areas, the scarcity of substrates for epiphytic lichens can be a serious limiting factor for the feasibility of biomonitoring studies (PIRINTsos \& Loppi, 2003).

Semi-arid Mediterranean area naturally features poor vegetation cover, principally represented by the semi-arid Mediterranean woodland or scrub. The cover of the shrubby layer $(0.8-8 \mathrm{~m})$ is $>20 \%$, the cover of the layer above $8 \mathrm{~m}$ is $<20 \%$ (ADAMS \& FAURE, 1995 ), and vegetation, as an integral part of terrestrial bio-productive system, is biased here by spreading desertification risk (Costantini et al., 2004; L'ABATE et al., 2004). Further, the widespread exploitation of the soil for agricultural purpose plays an important role in reducing the availability of suitable trees.

In northern and central Italy, recent biomonitoring studies (Giordani et al., 2001; Giordani et al., 2002; Brunialti \& Giordani, 2003; LopPi et al., 2002a,c, Frati \& Brunialti, 2005; Castello \& Skert, 2005) used tree-species with subacidic bark (e.g. Castanea sativa, Larix decidua, Quercus spp., Tilia spp.) which are not commonly available in semi-arid areas of the south (FEnAROLI \& GAMBI, 1976) for the above mentioned reasons.

The aim of this paper is to present the results of a case study carried out using LDV method in a semi-arid area of South Italy. The reason for the study was to find out whether modifications in the composition of lichen assemblages caused by the operation of the industrial zone in Pisticci Scalo exist.

\section{Study area}

The study area (ca. $36 \mathrm{~km}^{2}$ ) is situated in the valley of the river Basento (Val Basento), close to the town of Pisticci, $30 \mathrm{~km} \mathrm{SW}$ of the town of Matera, region of Basilicata (Fig. 1). It covers the river basin (alt. ca. $50 \mathrm{~m}$ a.s.l.) bordered by clay badlands on SW and NE, and surrounding 


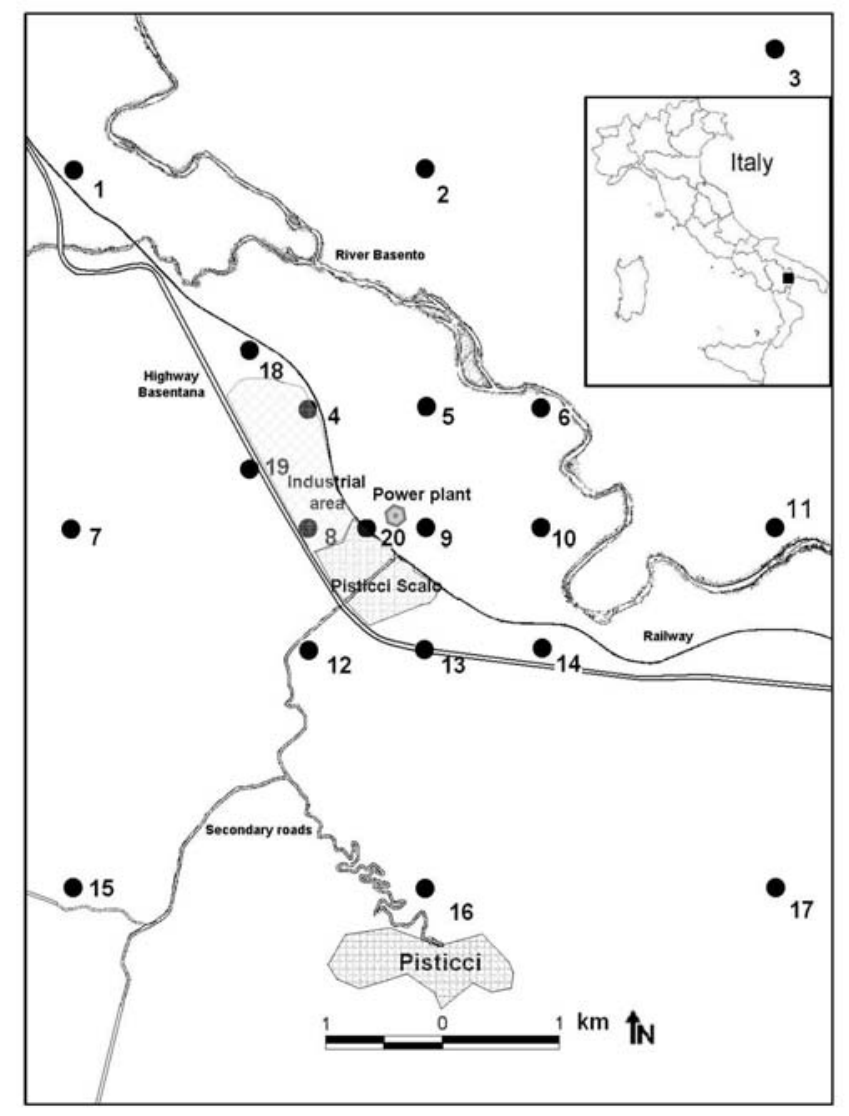

Fig. 1. The study area with location of the 20 investigated sampling units.

hills in W, S and E direction (alt. up to $400 \mathrm{~m}$ a.s.l.). Most of the area is rural (arable land, olive and citrus orchards). Badlands, if not remodelled and thus used for agricultural purposes are basically poorly-vegetated, unvegetated or occasionally afforested by eucalyptus trees. In the SW part compact and stable hill-slopes are partly forested with $P i$ nus pinaster, while in the NE part shrubby vegetation dominated by Pistacia lentiscus prevails.

The core part of the studied area around the settlement unit Pisticci Scalo is an industrial zone with a $68 \mathrm{MW}$ power plant running on methane, and ca. 15 small- and mediumsize mostly chemical enterprises (production of polymers, resin, nylon). The area is crossed from NW to ESE by the highway Basentana, which runs close to Pisticci Scalo. Five $\mathrm{km} \mathrm{SW}$ of the residential district there are posts of extraction of natural gas (principally methane with varying quantities of other hydrocarbon gases).

The area is characterized by a semi-arid Mediterranean climate: long dry periods in summers with temperature $>40{ }^{\circ} \mathrm{C}$ and relative humidity $<40 \%$. More than $65 \%$ of precipitation falls during autumn and winter. Annual rainfall values range within an interval 319-899 mm (CLARKE \& RENDELL, 2000).

\section{Material and methods}

The study area was investigated in the period of June-July 2003. Twenty sampling units were investigated, each of an area $1 \times 1 \mathrm{~km}$ (Fig. 1). Seventeen of them were selected following a systematic sampling design: the following nine (4, $5,6,8,9,10,12,13,14)$ with a sampling density of $1 \times 1 \mathrm{~km}$ cover the industrial part of the area, whereas the remaining eight $(1,2,3,7,11,15,16,17)$ with a sampling density of $3 \times 3 \mathrm{~km}$ cover the surroundings. Sampling units 18-20 were added to obtain detailed information on the industrial area $(18,19)$ and the residential district $(20)$ adjacent to the power plant.

Sampling was carried out according to the latest standards for mapping the lichen diversity as an indicator of environmental quality (ANPA, 2001, ASTA et al., 2002a), slightly modified to conform requirements of this study and the peculiarity of the investigated area. For each unit the $3(4)$ trees closest to the centre of the unit were sampled: the trees were deemed suitable if well-lit, with girth $>60 \mathrm{~cm}$, straight trunk, not damaged, and without parts with $>25 \%$ cover of bryophytes.

The lack of the most common tree-species with a subacidic bark (NIMIs, 1999) led us to select spontaneously growing Pyrus-trees as they were the most suitable in the study area. Pyrus sp. is frequently growing in rural semiarid areas of southern Italy, particularly along secondary roads and field borders. If not present, Ulmus sp., alternatively Amygdalus sp. were selected. In total, Pyrus sp. were sampled in 14 sampling units, Ulmus sp. in 5 of them and Amygdalus sp. in 1 sampling unit.

The LDVs were obtained as the sum of frequencies of epiphytic lichens in a sampling grid consisting of 4 ladders of $50 \times 10 \mathrm{~cm}$, each divided into 5 quadrates of $10 \times 10 \mathrm{~cm}$. The ladders were positioned on the tree-trunks in correspondence to the 4 aspects (N, S, E, W), ca. $100 \mathrm{~cm}$ from the ground. Each ladder represents a single relevé. Every sampled tree was geo-referenced to make repetition of the study possible in the future. Each sampling unit was characterized by LDV (arithmetic mean of the LDVs measured for each tree) and basic statistical parameters (standard deviation, coefficient of variation).

Because of the lack of an interpretative scale for the semi-arid Mediterranean bioclimatic area, a calibrated scale according to the protocol suggested by LOPPI et al. (2002b), for the assessment of environmental deviation from "nor$\mathrm{mal} /$ natural" conditions in the study area has been developed. Naturality was estimated in a hilly zone relatively distant from the industrial area (adjacent to the unit 7).

Similarity of floristic composition of 211 lichen-relevés (characterized by values of frequencies from 1 to 5) and ecological requirements of 34 species were analyzed according to ASTA et al. (2002b). For classification, Ward method (incremental sum of squares) was used as a clustering algorithm, with Euclidean distance as a resemblance measure using SYN-TAX 2000 software (PODANI, 2001). The ordination of the relevés was performed by principal component analysis (SAS Institute, 2000) considering the following variables: LDV of the relevé, tree species (Pyrus, Ulmus, Amygdalus), tree girth, aspect of the relevé ( $\mathrm{N}, \mathrm{E}, \mathrm{S}, \mathrm{W})$, tree location and position (plain, slopes), gradient of slope, site context (rural land of the basin, slopes with shrubby vegetation, slopes with tree vegetation, residential area, industrial area), altitude, distance from industrial core, distance from the closest pollution source and type of the closest pollution source. Spearman correlation coefficients were computed to eliminate pairs of highly correlated variables from the analysis. 
Nomenclature of lichens follows Nimis (2003). Voucher specimens of interesting taxa are deposited in SIENA (Department of Environmental Science, University of Siena, Italy). Maps were drawn using the plotting software SURFER 7.0 (Golden Software Inc., Colorado, USA).

\section{Results and discussion}

Evaluation of lichen diversity values

A total of 34 lichen species was recorded during the study, mostly belonging to the genera Caloplaca, Candelariella, Lecanora, Physcia and Phaeophyscia (Tab. 1). Hyperphyscia adglutinata was present in all the sampling units, Physcia biziana and Xanthoria parietina in $95 \%$ of them. Twenty-seven species were sampled on Pyrus sp., 21 on Ulmus sp. Eighteen of them were found on both the substrates. An individual of Pyrus, as well as that of Ulmus, hosted in average 5 lichen species (maximum 13 and 9 respectively).

The LDV counts can be taken as estimates of environmental quality: low LDVs indicate situations of strong deviation from the normal/natural condition (LopPI et al., 2002b), while high values generally correspond to better environments. Such measures are chiefly depending on the two main reactions of epiphytic lichen communities to air pollution: a decrease in the number of species and in their cover/frequency (NIMIs, 1999). The LDVs calculated for the tree-substrates ranged from 0 to 101 for Pyrus, and from 3 to 78 for Ulmus. Their mean values and coefficients of variation were $37 \pm 28(75 \%)$ and $33 \pm 24(73 \%)$ respectively, reflecting heterogeneous conditions within the sampling sites. Given that Amygdalus was sampled just in one site (7), mean LDV was $60 \pm 9$, with a coefficient of variation $16 \%$ and a maximum of 10 lichen species per tree. Naturality of the study area was set to LDVs > 75 for all the 3 substrates. The calibrated interpretative scale comprises 5 different classes of environmental alteration (Tab. 2).

Mean LDV for the study area was $37 \pm 23$ with a range of 14 to 64 . The large coefficient of variation $(73 \%)$ points to heterogeneous conditions in environmental quality within the area. Despite lichen desert was not present, the industrial-residential district of Pisticci Scalo (represented by sites 4, 8, 9, 18, 19 and 20) features a situation of general environmental alteration (Fig. 2). The mean LDV in this part of the study area was $25 \pm 8$. The sampling units $1,8,9,14,18,19$ and 20 are classified in the category of altered environment, (LDVs range from 14 to 25 , Tab. 3), while the surrounding sites $(4,10,12,13,15$ and 17), are classified in semi-altered environment, with LDVs ranging from 27 to 44 . LDVs tend to increase with the distance as well as the direction from the core of the study area, reaching a mean value of $46 \pm 15$ in the outer sampling sites. Only the sampling units 15 in SW direction, where the natural gas extraction is in operation and 1, close to the highway Basentana in NW direction, have low mean
Table 1. Lichen species recorded during the survey, percentage of occurrence $(\mathrm{P} \%)$, percentage of frequency $(\mathrm{F} \%)$ on total LDVs and species group according to the results of cluster analysis.

\begin{tabular}{lrrr}
\hline \multicolumn{1}{c}{ Species } & P $\%$ & F $\%$ & Species group \\
\hline Hyperphyscia adglutinata & 100 & 32.40 & 3 \\
Physcia biziana & 100 & 26.35 & 3 \\
Xanthoria parietina & 95 & 16.90 & 3 \\
Rinodina pyrina & 75 & 4.30 & 2 \\
Phaeophyscia orbicularis & 70 & 4.15 & 1 \\
Physcia adscendens & 70 & 4.35 & 1 \\
Lecanora horiza & 50 & 2.85 & 1 \\
Caloplaca cerinella & 45 & 4.40 & 2 \\
Lecidella elaeochroma & 45 & 1.50 & 1 \\
Lecanora chlarotera & 40 & 0.85 & 1 \\
Caloplaca cerina & 30 & 2.35 & 1 \\
Lecania cyrtella & 25 & 0.50 & 1 \\
Diplotomma alboatrum & 20 & 0.40 & 1 \\
Lecanora hagenii & 20 & 0.30 & 1 \\
Phaeophyscia chloantha & 20 & 1.35 & 1 \\
Xanthoria polycarpa & 20 & 0.70 & 1 \\
Candelariella reflexa & 15 & 0.60 & 1 \\
Phaeophyscia hirsuta & 15 & 0.70 & 1 \\
Caloplaca pyracea s. 1. & 10 & 1.50 & 1 \\
Caloplaca ulcerosa & 10 & 0.90 & 1 \\
Amandinea punctata & 5 & 0.25 & 1 \\
Caloplaca cerinelloides & 5 & 0.50 & 1 \\
Caloplaca pollinii & 5 & 0.05 & 1 \\
Candelariella viae-lacteae & 5 & 0.50 & 1 \\
Candelariella vitellina & 5 & 0.40 & 1 \\
Candelariella xanthostigma & 5 & 0.15 & 1 \\
Catillaria nigroclavata & 5 & 0.25 & 1 \\
Naetrocymbe punctiformis & 5 & 0.95 & 1 \\
Pachyphiale carneola & 5 & 0.25 & 1 \\
Parmelina tiliacea & 5 & 0.10 & 1 \\
Physcia aipolia & 5 & 0.10 & 1 \\
Physcia dubia & 5 & 0.65 & 1 \\
Physconia grisea & 5 & 0.20 & 1 \\
Physconia servitii & 5 & 0.05 & \\
\hline & & & \\
\hline
\end{tabular}

Table 2. Interpretative scale of LDVs for the study area.

\begin{tabular}{ccc}
\hline LDV & $\begin{array}{c}\% \text { Deviation from } \\
\text { normal conditions }\end{array}$ & $\begin{array}{c}\text { Interpretation in terms } \\
\text { of environmental alteration }\end{array}$ \\
\hline 0 & 100 & very high (lichen desert) \\
$1-25$ & $>75-99$ & high (altered environment) \\
$25-50$ & $>50-75$ & moderate (semi-altered environment) \\
$50-75$ & $>25-50$ & low (semi-natural environment) \\
$>75$ & $0-25$ & negligible (natural environment) \\
\hline
\end{tabular}

LDV (19 and 30 respectively). The very marginal sites $(2,3,5,6,7,11$ and 16), reaching top LDVs within the interval 51-64 are classified in semi-natural environment. In the NE direction a rise of mean LDVs with a 2.4-increasing factor compared with the core of the study area is evident (sites 5 and $6, \mathrm{LDV}=52$ and 64 respectively). Although a general improvement of environmental quality according to LDVs in the rural surrounding area was evident, none of the sampling site was classified as natural environment. 
Table 3. Mean LDV, standard deviation (SD) and coefficient of percentage variation (CV\%) for the 20 sampling units (SU).

\begin{tabular}{lrrrrrrrrrrrrrrrrrrrrr}
\hline SU & 1 & 2 & 3 & 4 & 5 & 6 & 7 & 8 & 9 & 10 & 11 & 12 & 13 & 14 & 15 & 16 & 17 & 18 & 19 & 20 \\
\hline LDV & 19 & 51 & 51 & 42 & 52 & 64 & 60 & 25 & 17 & 34 & 63 & 32 & 28 & 14 & 30 & 51 & 44 & 21 & 24 & 23 \\
SD & 11 & 40 & 8 & 39 & 31 & 27 & 10 & 26 & 12 & 46 & 43 & 17 & 28 & 7 & 13 & 22 & 33 & 23 & 22 & 10 \\
CV\% & 58 & 78 & 16 & 93 & 60 & 42 & 17 & 104 & 71 & 135 & 68 & 53 & 100 & 50 & 43 & 43 & 75 & 110 & 92 & 43 \\
\hline
\end{tabular}

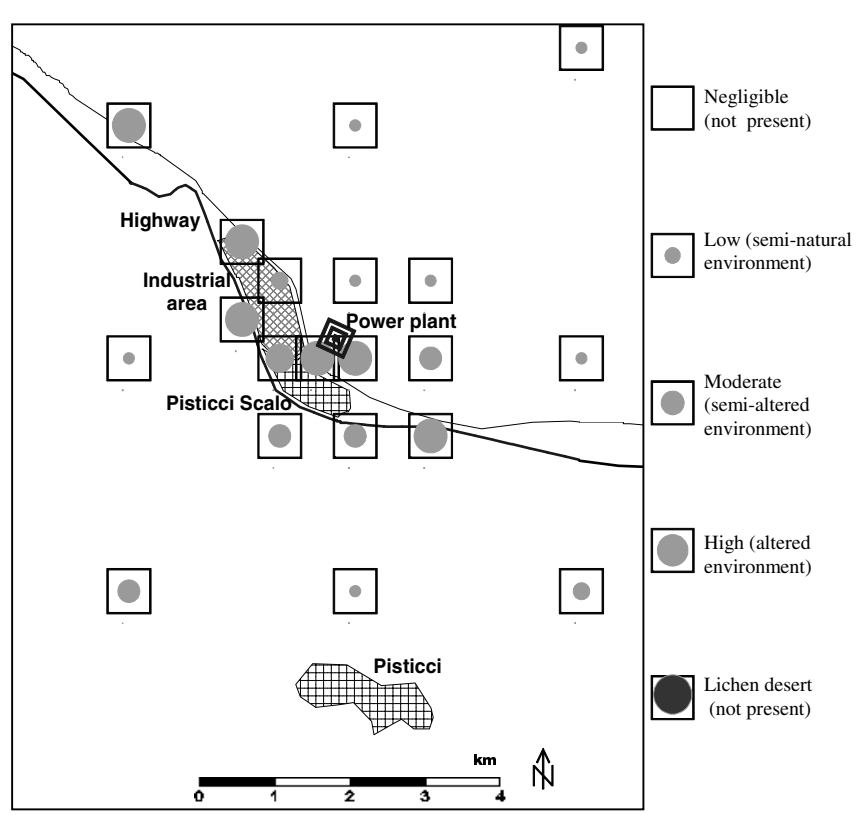

Fig. 2. Graphical interpretation of LDVs in terms of environmental alteration.

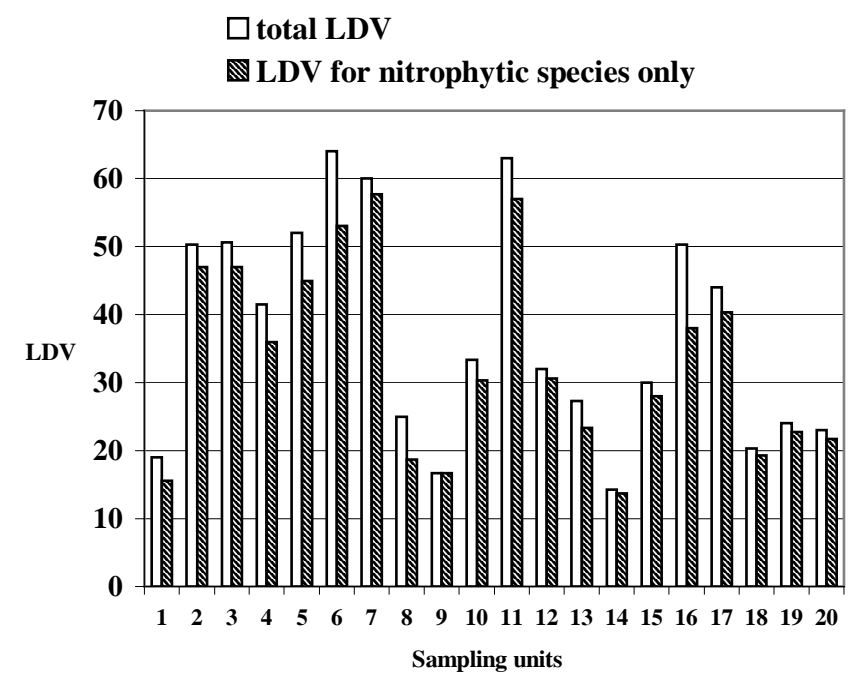

Fig. 3. Total measured LDVs vs LDVs considering only nitrophytic species according to Nimis (2003).

Because of the heterogeneous ecological conditions and the scarcity of suitable trees, a relatively high variability in the results was sometimes found within few sampling units. These units were thus attributed to a corresponding class of environmental quality with some degree of uncertainty. However, lichen biomonitoring surveys of small areas (e.g. LopPI, 1996; LopPI et al., 2002c; Loppi \& CoRsini, 2003; PIRINTsos et al. 2003) confirmed high variability of data when a rapid rise in LDVs was recorded with increasing distance from a pollution source.

Apart from air pollution, lichen diversity is influenced by other factors as well, e.g. climate, substratum, land use activities (BARKMAN, 1958; BRUNIALTI \& Giordani, 2003; Giordani, 2005; Frati et al., 2005). Noteworthy, $95 \%$ share of total recorded lichen frequencies was that of nitrophytic (and mostly xerophytic) species sensu Nimis (2003), such as Hyperphyscia adglutinata, Physcia biziana, Xanthoria parietina, Caloplaca cerinella, Rinodina pyrina, Phaeophyscia orbicularis and Physcia adscendens (Tab. 1) suggesting a secondary eutrophicated bark of sampled trees within all the sites (Fig. 3). According to LOPPI \& De Dominicis (1996), Loppi et al. (1998), Pirintsos et al. (1998) the xeric conditions and rural-agricultural environment indirectly support dust impregnation of the bark and the drier microclimate of trees in the Mediterranean area, enhancing xero-nitrophytic lichen species diffusion. In our survey area, where for the above mentioned reasons fruticose and meso-acidophytic foliose sensitive species (BARKMAN, 1958) were lacking, the sampled flora was mainly composed by crustose growth forms $(62 \%)$, while the remaining part was dominated by narrow-lobe foliose species. The existing air pollution principally affected crustose and narrow-lobe xero-nitrophytic species, as they were those mainly diffused. A decline in species number was thus evident proceeding from semi-natural sites to the altered ones, which showed as an average 4 and 2 species per tree respectively.

\section{Analysis of lichen diversity}

Multivariate analysis produced 11 main groups of relevés (Fig. 4A) and 3 main lichen-species groups (Fig. 4B). The results concerning relevés are summarized in Tab. 4. The breakdown of the species is included in Tab. 1. Common feature of the relevés is the presence of nitrophytic, photophytic and xerophytic species predominantly of the alliance Xanthorion parietinae OCHSNER 1928 emend. BARKMAN 1958.

Two main clusters of relevés are identified in the dendrogram (Fig. 4A). The first level of division is used for interpretation. From sociological viewpoint, the groups are indeterminate lichen-association types which can be assigned to serial stages of Physci- 
A

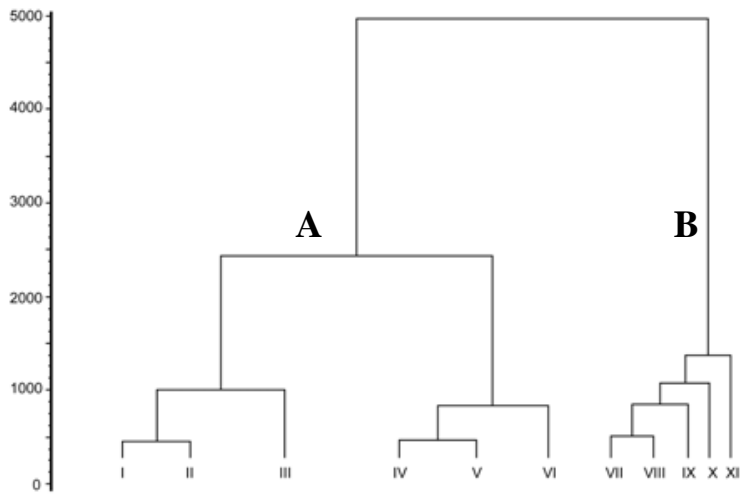

Closest pollution source
B

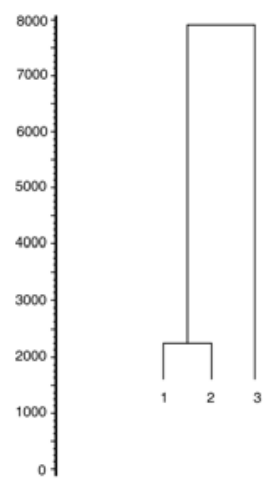

Fig. 4. Dendrograms of numerical classification of 211 relevés (A) and 34 species (B)

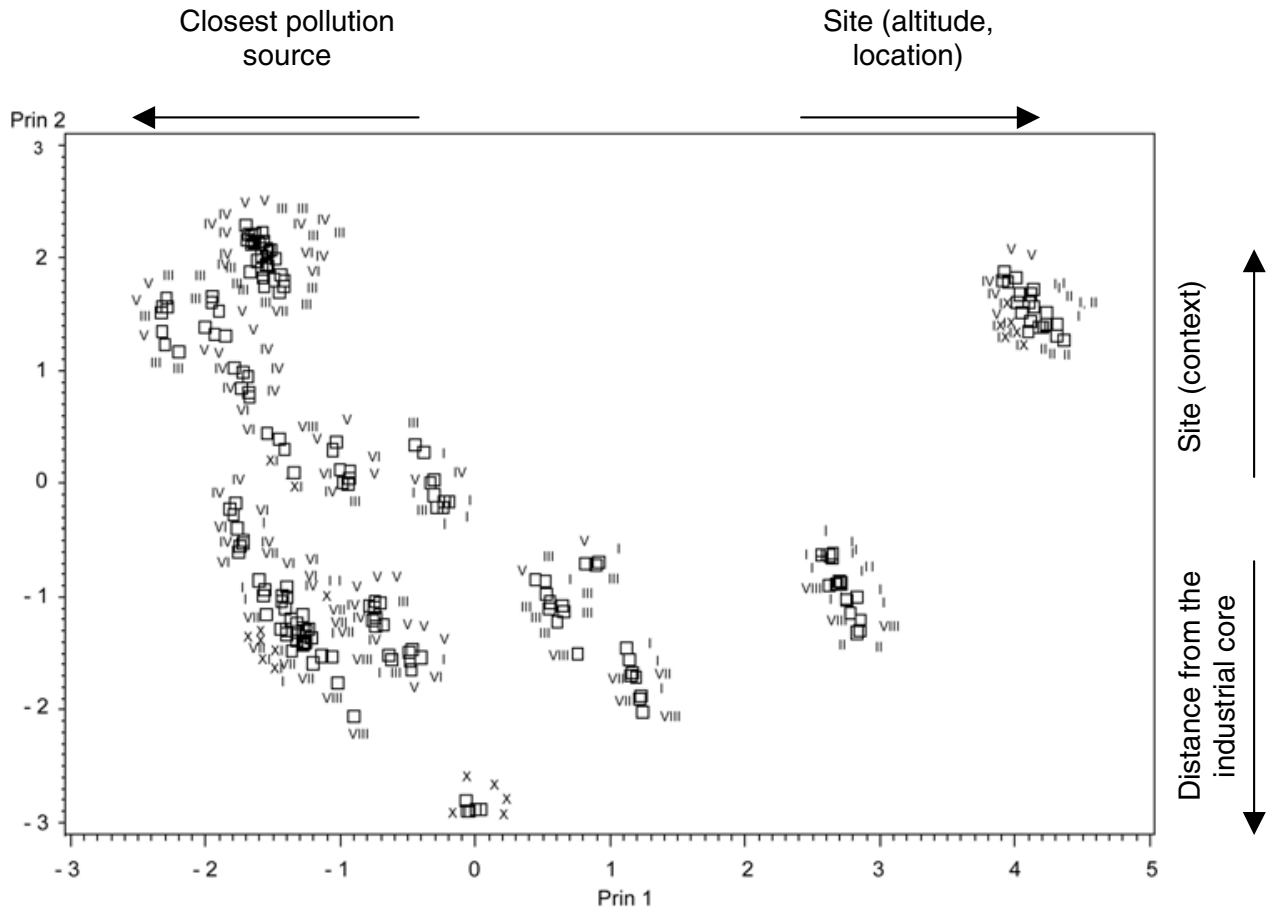

Fig. 5. Principal component analysis (PCA) ordination diagram of 211 lichen-relevés. Numbers I-XI indicate main relevé-groups. etum elaeinae BARKMAN 1958 combined with the remains of its usual predecessor associations of the alliance Lecanorion variae (cf. Caloplaca cerinella, Lecania cyrtella, Rinodina pyrina) [BARKMAN, 1958]. The cluster A comprises the groups I-VI, the cluster B includes the groups VII-XI. Comparing the clusters, in the A crustose layer dominates foliose one, the overall species diversity is richer, but LDVs are generally lower. In B foliose layer dominates the crustose one and LDVs are greater: these communities are confined to semi-natural sites of the study area and do not reach the core sampling units. The lichen species were classified in 3 groups according to their ecological demands. The group 3 comprises local Xanthorion ubiquists, $H y$ perphyscia adglutinata, Physcia biziana and Xanthoria parietina. The group 2 includes two crustose species of the alliance Lecanorion variae: Caloplaca cerinella and
Rinodina pyrina. The group 1 covers sporadically registered foliose and crustose species of both alliances.

In ordination diagram (Fig. 5) the relevé-groups show continuities along the first two axes. The first axis represents $34 \%$ and the second one $16 \%$ of the total variance. On the whole, the ordination showed a negative effect of air pollution sources on lichen diversity. Despite the differences in ecological conditions throughout the study area, the relevés shared common species with wide ecological amplitude (e.g. from the speciesgroups 2 and 3 ).

The first axis was positively correlated to site altitude and location, and negatively to the type of the closest pollution source. The gradient is defined by the groups II and XI for positive values of the axis (Fig. 5), comprising the relevés taken on the slopes, in seminatural sites. For negative values of the first axis the 
Table 4. Composition of the 11 main relevé groups defined by cluster analysis.

\begin{tabular}{|c|c|c|c|c|c|c|c|c|c|c|c|}
\hline Group & $\mathrm{I}$ & II & III & IV & $\mathrm{V}$ & VI & VII & VIII & IX & $\mathrm{X}$ & XI \\
\hline Number of relevés & 35 & 9 & 32 & 31 & 27 & 21 & 19 & 12 & 9 & 7 & 9 \\
\hline Mean LDV & 10.3 & 18.4 & 7.6 & 2.8 & 4.5 & 6.3 & 14.8 & 23.7 & 20.7 & 23.7 & 23.3 \\
\hline Standard deviation & 3.6 & 2.4 & 3.6 & 2.1 & 3.9 & 4.5 & 5.3 & 5.3 & 4.1 & 2.5 & 4.5 \\
\hline Pyrus $(\%)$ & 86 & 33 & 56 & 45 & 81 & 67 & 89 & 83 & 33 & 87 & 78 \\
\hline Ulmus (\%) & 0 & 0 & 44 & 55 & 19 & 28 & 11 & 17 & 67 & 13 & 22 \\
\hline Amygdalus (\%) & 14 & 67 & 0 & 0 & 0 & 5 & 0 & 0 & 0 & 0 & 0 \\
\hline $\mathrm{N}(\%)$ & 28 & 33 & 25 & 10 & 18 & 24 & 37 & 42 & 33 & 29 & 33 \\
\hline $\mathrm{E}(\%)$ & 24 & 33 & 22 & 42 & 30 & 28 & 16 & 25 & 11 & 29 & 33 \\
\hline $\mathrm{S}(\%)$ & 20 & 22 & 22 & 35 & 26 & 14 & 21 & 8 & 11 & 13 & 22 \\
\hline $\mathrm{W}(\%)$ & 28 & 12 & 31 & 13 & 26 & 34 & 26 & 25 & 45 & 29 & 12 \\
\hline
\end{tabular}

corresponding relevés were sampled prevalently in the basin with altered ambiental conditions (altitude ca. $50 \mathrm{~m}$ a.s.l.), closer to the pollution sources of the area. In general, this suggests that at the sites with higher LDVs lichen frequencies and variations in the epiphytic lichen communities do not seem to be affected by air pollution, but presumably depend on other environmental factors, as already reported by LopPI et al. (2002d).

The second axis is positively correlated to the site context and negatively to the distance from industrial core and the closest pollution source. The gradient starts with the group IX downwards (representing relevés sampled in the marginal sites outside the basin - in vegetated areas distant from the industrial core) through the group XI, finishing with the groups VII, VIII and $\mathrm{X}$, which generally include the relevés from the basin close to the industrial area.

In conclusion we can state that LDV counts enabled to zone the survey area according to the level of environmental alteration. The location of the altered sites correlates chiefly with the position of the industrial core. Multivariate classifications revealed further factors (site context, altitude and exposure of a tree), which are responsible for modifications in species composition within the lichen assemblages in the better class sites of the area.

Previous bioindication studies in dry Mediterranean areas, namely in Greece (DiAmANTOPOULOS et al., 1992; Pirintsos et al., 1993; VoKOU et al., 1999), employed Pinus brutia trees as a suitable substrate for lichen diversity measures. As $P$. brutia lacks in drier areas of northern Greece it was substituted by Quercus coccifera bushes (PIRINTsos et al., 2003) and consequently by the application of a different sampling procedure (DERUElle \& GARCIA-SCHAEFFER, 1983). In our case study, mainly the use of Pyrus trees assured the feasibility of the investigation. However, as it has been shown for Greece (PIRINTsos et al., 2003), as well in several arid areas of southern Italy (e.g. Sardinia, Sicily, Puglia) the scarcity of standard trees could seriously hamper field sampling according to the actual requirements of LDV methods (ANPA, 2001, AsTA et al., 2002). Therefore, the improvement of the method- ology accounting the peculiarities of semi-arid and dry Mediterranean environments should be addressed as an important goal to use lichens effectively for bioindication studies in such areas.

\section{Acknowledgements}

We are indebted to the reviewers for valuable suggestions to the manuscript, further, to M. VALACHOVIČ, J. ŠBí́, M. Slovák, M. PERnÝ (Bratislava) and J. TOPERCER (Blatnica) for assistance and comments to multivariate methods. We are grateful to Energia Progetti Srl for financing the study. The work was partly supported by the project VEGA 4035.

\section{References}

AdAms, J.M. \& FAure, H. (eds) 1997. QEN members. Review and Atlas of paleovegetation: Preliminary land ecosystem maps of the world since the Last Glacial Maximum. Oak Ridge National Laboratory, TN, USA. www.soton.ac.uk/ $\sim$ tjms/adams1.html.

AnPA, 2001. I. B. L. Indice di Biodiversità Lichenica. Manuali e Linee Guida 2/2001. 43 pp.

Asta, J., Erhardt, W., Ferretti, M., Fornasier, F., Kirschbaum, U., Nimis, P.L., Purvis, O.W., Pirintsos, S., Scheidegger, C., van Haluwyn, C. \& Wirth, V. 2002a. Mapping lichen diversity as an indicator of environmental quality, pp. 273-279. In: Nimis, P.L., ScheideGGER, C. \& Wolseley, P.A. (eds), Monitoring with Lichens Monitoring Lichens, Kluwer Academic Publishers, Dordrecht, Boston, London.

Asta, J., Erhardt, W., Ferretti, M., Fornasier, F., Kirschbaum, U., Nimis, P.L., Purvis, O.W., Pirintsos, S., Scheidegger, C., van Haluwyn, C. \& Wirth, V. 2002b. European guideline for mapping lichen diversity as an indicator of environmental stress. http: users.argonet.co.uk/users/jmgray/eurnap.pdf

BARKMAN, J.J. 1958. Phytosociology and ecology of cryptogamic epiphytes. Assen. 628 pp.

Brunialti, G. \& Giordani, P. 2003. Variability of lichen diversity in a climatically heterogeneous area (Liguria, NW Italy). Lichenologist 35: 55-69.

Castello, M. \& Skert, N. 2005. Evaluation of lichen diversity as an indicator of environmental quality in the North Adriatic submediterranean region. Sc. Tot. Environ. 336: 201-214.

Clarke, M.L. \& Rendell, H.M. 2000. The impact of the farming practice of remodelling hillslope topography on badland morphology and soil erosion processes. Catena 41: 229-250.

Costantini, E.A.C., Bocci, M., L'ABAte, G., Fais, A., Leone, G., Loj, G., Magini, S., Napoli, R., Nino, P. \& Urbano, 
F. 2004. Mapping the state and risk of desertification in Italy by means of remote sensing, soil GIS and the EPIC model. Methodology validation in the Sardinia Island, Italy. International Symposium: Evaluation and Monitoring of Desertification. Synthetic Activities for the Contribution to UNCCD, Tsukuba, Ibaraki, Japan, February 2, 2004, NIES publication, 12 pp.

Deruelle, S. \& Garcia-Schaeffer, F. 1983. Les lichens bioindicateurs de la pollution atmosphérique dans la région Parisienne. Cryptogamie Bryol. Lichénol. 4: 47-64.

Diamantopoulos, J., Pirintsos, S.A., Laundon, J.R. \& VoKOU, D. 1992. The epiphytic lichens around Thessaloniki (Greece) as indicators of sulphur dioxide pollution. Lichenologist 24: $63-71$.

Fenaroli, L. \& Gambi, G. 1976. Alberi, Dendroflora Italica. Museo di Scienze Naturali, Trento, $717 \mathrm{pp}$.

Frati, L. \& Brunialti, G. 2005. Long-term biomonitoring with lichens. Comparing data with different sampling procedures. Environ. Monit. Assess. (in press).

Frati, L., Santoni, S., Nicolardi, V., Gaggi, C., Brunialti, G., Guttova, A., Gaudino, S., Pati, A., Pirintsos, S.A. \& LOPPI, S. 2005. Lichen biomonitoring of ammonia emission and nitrogen deposition around a pig stockfarm. Environ. Pollut. (in press).

Giordani, P. 2005. Is the diversity of epiphytic lichens a reliable indicator of air pollution? A case study from Italy. Environ. Pollut. (in press).

Giordani, P., Brunialti, G. \& Modenesi, P. 2001. Applicability of the lichen biodiversity method (L.B.) to a Mediterranean area (Liguria, nw Italy). Cryptogamie, Mycol. 22(3): 193-208.

Giordani, P., Brunialti, G. \& Alleteo, D. 2002. Effects of atmospheric pollution on lichen biodiversity (LB) in a Mediterranean region (Liguria, northwest Italy). Environ. Pollut. 118: 53-64.

L'Abate, G., Costantini, E.A. C. \& Urbano, F. 2004. Estimating soil drought risk in Italy using the EPIC model and a pedoclimatic GIS. www.soilmaps.it/download/cli-icdl4.pdf.

LOPPI, S. 1996. Lichens as bioindicators of geothermal air pollution in central Italy. Bryologist 99: 41-48.

LOPPI, S. \& CORSINI, A. 2003. Diversity of epiphytic lichens and metal contents of Parmelia caperata thalli as monitors of air pollution in the town of Pistoia (C Italy). Environ. Monit. Assess. 86: 289-301.

Loppi, S. \& De Dominicis, V. 1996. Effects of agriculture on epiphytic lichen vegetation in Central Italy. Isr. J. Plant Sci. 44: 297-307.

Loppi, S., Frati, L., Benedettini, G., Pirintsos, S.A. \& LEONZIO, C. 2002a. Biodiversity of epiphytic lichens as indicator of air pollution in the geothermal area of Larderello (Tuscany, Central Italy). Isr. J. Plant Sci. 50: 119-126.
Loppi, S., Giordani, P., Brunialti, G., Isocrono, D. \& Piervittori, R. 2002b. Identifying deviations from naturality of lichen diversity for bioindication purposes, pp. 281-284. In: Nimis, P.L., ScheidegGer, C. \& Wolseley, P.A. (eds), Monitoring with Lichens - Monitoring Lichens, Kluwer Academic Publishers, Dordrecht, Boston, London.

Loppi, S., Destito, G., Pirintsos, S.A. \& De Dominicis, V. 2002c. Temporal variation of air pollution in a geothermal area of central Italy: assessment by the biodiversity of epiphytic lichens. Isr. J. Plant Sci. 50: 45-50.

Loppi, S., Boccardi, R. \& Ivanov, D. 2002d. Biodiversity of epiphytic lichens and air pollution in the town of Siena (Central Italy). Environ. Pollut. 116: 123-128.

Loppi, S., Pirintsos, S., Sforzi B. \& De Dominicis, V. 1998. Effects of climate and agriculture on epiphytic lichen vegetation in the Mediterranean area (Tuscany, Central Italy). Acta Bot. Croat. 55/56: 17-27.

Nimis, P.L. 2003. Checklist of the lichens of Italy 3.0. University of Trieste, http://dbiodbs.univ.trieste.it.

Nimis, P.L. 1999. Linee-guida per la bioindicazione degli effetti dell'inquinamento tramite la biodiversità dei licheni epifiti, pp. 267-277. In: Piccini, S. \& Salvati, S. (ed.), Atti del Workshop "Biomonitoraggio della Qualità dell'Aria sul Territorio Nazionale", Roma, 26-27 novembre 1998, ANPA, Serie Atti 2/1999.

Nimis, P.L., Scheidegger, C. \& Wolseley, P.A. (eds) 2002. Monitoring with Lichens - Monitoring Lichens. Kluwer Academic Publishers, Dordrecht, Boston, London, 403 pp.

Pirintsos, S.A. \& LOPPI, S. 2003. Lichens as bioindicators of environmental quality in dry Mediterranean areas: a case study from northern Greece. Isr. J. Plant Sci. 51: 143-151.

Pirintsos, S.A., Loppi, S., Dalaka, A. \& De Dominicis, V. 1998. Effects of grazing on epiphytic lichen vegetation in a Mediterranean mixed evergreen sclerophyllous and deciduous shrubland (Northern Greece). Isr. J. Plant Sci. 46: 303-307.

Pirintsos, S.A., Vokou, D., Diamantopoulos, J. \& GalLOWAY, D.J. 1993. An assessment of the sampling procedure for estimating air pollution using epiphytic lichens as indicators. Lichenologist 25: 165-173.

PODANI, J. 2001. SYN-TAX 2000. Computer Programs for Data Analysis in Ecology and Systematics. User's manual. Scientia Publishing, Budapest.

SAS Institute 2000. SAS OnlineDoc ${ }^{\circledR}$, version 8 (available online). SAS Institute, Cary.

Vokou, D., Pirintsos, S.A. \& Loppi, S. 1999. Lichens as bioindicators of temporal variations in air quality around Thessaloniki, northern Greece. Ecol. Res. 14: 89-96.

Received April 12, 2005 Accepted Nov. 10, 2005 